\title{
Diabetes Mellitus in Climacteric: Prevalence and Sociodemographic Characteristics
}

Alberto Oliveira da C. Mota1, Raissa Oliveira C. Nunes², Claudia Jeane L. Pimenta ${ }^{3}$, Francisco Geyson F. Albuquerque1, Letícia Sampaio C. Silva1, Andreia C. Campigotto4, Francisco Fábio M. da Silva ${ }^{5}$, Kévia Katiúcia S. Bezerra ${ }^{4}$, Maria do Carmo A. Duarte de Farias ${ }^{6}$

\section{Abstract}

Introduction: The changes caused by menopause and the duration of this period in women's lives are of great scientific relevance, and achieving a better understanding of diseases such as diabetes prevalent in the climacteric and the risk factors associated with metabolic and cardiovascular diseases is essential.

Objective: To determine the prevalence of Diabetes Mellitus (DM) in climacteric women, correlating socioeconomic and demographic variables.

Method: This is a cross-sectional study with a quantitative approach, performed in 14 Family Health Units (USF) in the urban area of the municipality of Cajazeiras/Paraíba, Brazil, with 396 women. Data were collected in interviews using a structured questionnaire, and the variables were analyzed using the Statistical Package for Social Sciences (SPSS).

Results: There was prevalence of DM in 11.6\% $(n=396)$ of the climacteric women, who had DM as a single disease or associated with other diseases. Regarding the sociodemographic profiles and lifestyles of the diabetic women, it became evident that the 46 participants were on average 52.1 years old; had 5.2 years of formal education and per capita income of 0.7 minimum wage; $43.5 \%$ were in paid employment; $65.2 \%$ had a fixed partner; $23.9 \%$ reported being smokers; $15.2 \%$ reported use of alcohol; $73.9 \%$ said they were sedentary and $76.1 \%$ were overweight/obese.
1 Student of Medicine, Academic Unit of Life Sciences, Teacher's Training Center, Federal University of Campina Grande.

2 Student of Medicine, Academic Unit of Life Sciences, Center of Life Sciences and Health. Federal University of Campina Grande.

3 Bachelor of Nursing, Federal University of Campina Grande. Cajazeiras, Paraiba, Brazil.

4 Academic Unit of Life Sciences, Teacher's Training Center, Federal University of Campina Grande. Cajazeiras, Paraíba, Brazil.

5 Academic Unit of Nursing, Teacher's Training Center, Federal University of Campina Grande. Cajazeiras, Paraíba, Brazil.

6 Coordinator and counselor of research. Academic Unit of Life Sciences, Teacher's Training Center, Federal University of Campina Grande. Cajazeiras, Paraíba, Brazil.

\section{Contact information:}

Maria do Carmo A. Duarte de Farias.

झ" carmofarias0@gmail.com 
Conclusion: The relationship between the presence of risk factors, especially those associated with physical inactivity and overweight, and the prevalence of diabetes and other diseases in the climacteric was strengthened.

\section{Keywords}

Diabetic; Climacteric;

Community Health Services.

\section{Introduction}

Diabetes Mellitus (DM) is a group of metabolic disorders characterized by hyperglycaemia resulting from a deficit in insulin production, its action in the body, or both. It is divided into Types I and II, the first resulting from immune destruction of the $\nabla$ pancreatic cells and Type II a metabolic disorder of multiple aetiology characterized by chronic hyperglycaemia with disturbances in the metabolism of carbohydrates, fats and proteins originating from a defective secretion and/or insulin action in target tissues [1-3].

Even though DM has a lower prevalence than other diseases, it is a highly disabling disease which can lead to blindness, amputations, kidney diseases and cardiovascular and brain complications, among others, which cause damage to functional capacity, autonomy and quality of life of the individual [4].

The prevalence of Type II DM has increased in the west [5], with the highest prevalence being among individuals of ages 59 to 65 years, which makes climacteric women predisposed to developing the disease [6]. As the aging population is part of the demographic reality of Brazil, it is expected that in the coming years there will be a significant increase in climacteric women seeking health services [7].

The climacteric is considered a transition from the reproductive stage to the non-reproductive stage in the woman's aging process, marked by the menopause, which indicates the end of the reproductive period. This is a process that begins at 35 and ends at 65 years of age. Its main features are the physical and emotional changes resulting from the imbalance in the production of female hormones by the ovaries, which can simultaneously provoke the emergence of various diseases, with diabetes one of the most prevalent in this group [8-9].

The decrease in the production of ovarian hormones, with consequent sharp oestrogenic depletion, results in significant changes in the biophysical profile of postmenopausal women, culminating in an increase in the levels of visceral adiposity [10]. Thus, the climacteric coincides with the onset and aggravation of risk factors for the development of Metabolic Syndrome [11], with diabetes one of the most prevalent components of this syndrome [12].

Type II DM is a condition that has its development and evolution intrinsically associated with socioeconomic factors. Unhealthy habits of life, difficulty in accessing health services, and lack of knowledge regarding the prevention and control of this disease all contribute to its development and negatively influence the prognosis [13]. The climacteric itself is also strongly influenced by psychosocial factors, of which knowledge is essential for a more humanized and thus effective care [7].

In Brazil, especially in the north and northeast, studies that draw associations between components of the metabolic syndrome, such as diabetes and menopause, are extremely scarce [12].

The aim of this study is, therefore, to determine the prevalence of Diabetes Mellitus in climacteric women, correlating socioeconomic and demographic variables. 


\section{Method}

This is a cross-sectional study with a quantitative approach, performed in 14 Family Health Units (USF) in the urban area of the municipality of Cajazeiras/Paraíba, Brazil, between the months of January 2013 and March 2014. The population consisted of all women aged 35-65 years living in the city and the selection of the sample was calculated probabilistically, based on a sample calculation of finite population, adopting a 5\% significance level, the sampling error of 5\% and 95\% confidence interval, totalling 396 participants.

Inclusion criteria were: being female, in the age group of 40 to 60 years old and registered with the USF. This age group was defined because before the age of 40 climacteric symptoms are virtually absent, and over the age of 60, women rarely report climacteric complaints due to having physiologically adapted. Excluded were: women who did not have climacteric complaints, those who had undergone hysterectomies and hormone replacement therapy and/or those using hormonal contraceptives, as those are factors that interfere with the climacteric symptoms. The intensity of climacteric symptoms was assessed quantitatively by Blatt-Kupperman Menopausal Index (BKMI).

Data collection was conducted through structured-script interviews of women visiting the USF to undergo a Pap smear or a Hypertension and Diabetes Programme (HIPERDIA) consultation, as well as during home visits by community health agents.

This study took a quantitative approach, analyzing the variables statistically; The data collection instruments were listed sequentially. For the analysis and tabulation of data, the EXCEL program and the Statistical Package for Social Sciences (SPSS) version 22, free to download, was used.

The variables analyzed included sociodemographic and lifestyle data, and the presence of DM was confirmed by registering with the HIPERDIA programme, the self-report of interviewees and the use of medication specifically for the control of the disease. Variables were: age, education and per capita income, with the mean and standard deviation identified.

This research is part of the project "Symptoms of menopause: severity and associated factors," which was approved by the Research Ethics Committee of the State University of Paraíba -UEPB as protocol number $0462.0 .133 .000-11$, on $14^{\text {th }}$ September, 2011.

\section{Results}

396 climacteric women were interviewed, of which 188 (47.5\%) reported having some pathology, of which $46(11.6 \%)$ of these had DM as a single disease or associated with other diseases, as shown in Table 1.

Table 1. Clinical profile or the study participants, Cajazeiras - PB, 2013-2014. $(n=396)$

\begin{tabular}{|l|c|c|}
\multicolumn{1}{|c|}{ Variable } & $\mathbf{n}$ & $\%$ \\
\hline Presence of pathologies & & \\
\hline Yes & 188 & 47.5 \\
\hline No & 208 & 52.5 \\
\hline Hypertension and Diabetes & & \\
\hline \begin{tabular}{l|c|c|} 
Diabetes only \\
Hypertension and Diabetes
\end{tabular} & 14 & 3.5 \\
\hline $\begin{array}{l}\text { Diabetes and other diseases } \\
\text { Other diseases }\end{array}$ & 29 & 7.3 \\
\hline Diabetes & 142 & 35.9 \\
\hline Yes & 46 & 11.6 \\
\hline No & 350 & 88.4 \\
\hline \multicolumn{1}{|c|}{ Source: Field Research, 2013-2014. } \\
\hline
\end{tabular}

Regarding the sociodemographic and lifestyle profiles of the diabetic women, it became evident that the 46 participants were on average 52.1 years old; had 5.2 years of formal education and per capita income of 0.7 minimum wage; $43.5 \%$ were in paid employment; $65.2 \%$ had a fixed partner; $23.9 \%$ reported being smokers; $15.2 \%$ reported 
use of alcohol; 73.9\% said they were sedentary and $76.1 \%$ were overweight/obese. (Table 2)

Table 2. Sociodemographic and lifestyle profile of the diabetic women, Cajazeiras - PB, 20132014. $(n=46)$

\begin{tabular}{|l|c|c|}
\hline \multicolumn{1}{|c|}{ Variable } & $\mathbf{n}$ & $\%$ \\
\hline Age & & \\
\hline 40-50 years old & 15 & 32.5 \\
\hline 51-60 years old & 31 & 67.1 \\
\hline Formal education received & & \\
\hline 0-5 years & 22 & 47.7 \\
\hline 6-10 years & 13 & 28.3 \\
\hline 11-15 years & 11 & 23.9 \\
\hline Fixed partner & & \\
\hline Yes & 76.19 & 87.50 \\
\hline
\end{tabular}

Paid employment

Yes $20 \quad 43.5$

Family income by number of residents

$<1$ minimum wage

$34 \quad 73.8$

1-2 minimum wages

$12 \quad 26.1$

\section{Smoking}

Yes

$11 \quad 23.9$

\section{Alcohol use}

Yes

\begin{tabular}{l|l}
7 & 15.2
\end{tabular}

Sedentary lifestyle

Yes

\begin{tabular}{l|l}
$34 \quad 73.9$
\end{tabular}

BMI

Normal weight $11 \quad 23.9$

Overweight/obesity

$35 \quad 76.1$

BMI: Body Mass Index. Source: Field research, 2013-2014.

\section{Discussion}

The mean age shown in this study is similar to the results found in a study of 260 women in climacteric period in Recife, Brazil [14]. However, $63.5 \%$ of the women were in paid employment and almost half had a per capita income higher than one minimum wage.
Regarding the years of formal education received, there was a low level of education in the surveyed women; similar data were found by Leite et al. [15], in which 55\% of the sample reported having finished middle school. Another study [16], in the city of Natal, Rio Grande do Norte, found a low level of education. However, $64 \%$ of the sample reported having income greater than two minimum wages.

Analysis of the data from this study indicates the precariousness with regard to socioeconomic and educational conditions, as well as a relationship with risk factors associated with diabetes, which corroborates the findings of Lorenzi et al [8]. Considering this situation, it is necessary to conduct a thorough analysis of the sociodemographic conditions of women in the climacteric period, given that such conditions may be intrinsically linked to the emergence of diabetes and other associated diseases [13].

The research by Nascimento, Chaves and Grossi [17] emphasizes the importance of taking into account sociodemographic factors, their relationship and monitoring symptoms of depression in diabetic patients to better control the disease. It also presented data indicating that a lower income in diabetic patients resulted in a greater predisposition to depression and associated problems. Research carried out by Freitas and Garcia [18] found that the prevalence of diabetes associated with hypertension concomitantly increases with increasing age, and the highest prevalence of this is observed in women.

Regarding risk factors, similar results were found by Pereira, Barreto, and Passos [19], who evaluated the degree of physical inactivity, obesity, smoking and alcohol consumption. It is also noteworthy that in older women those elements were often associated with DM, hypertension and hypercholesterolaemia.

In contrast, Lorenzi et al. [8] point out and reinforce the theory that the prevalence of overweight and obesity in climacteric patients is strongly influenced by non-biological factors, reinforcing therefore the 
relationship between the prevalence of risk factors for DM with certain sociodemographic situations, such as those found in this study.

A multicentre study conducted in the UK in 1998, the United Kingdom Prospective Diabetes Study, confirmed that hypertension, hypercholesterolaemia and smoking are independently favourable to mortality from coronary artery disease, and the presence of at least one of these risk factors has greater impact on mortality in diabetic patients than in nondiabetic patients [20].

A patient with Type I diabetes has a reduction of about 15 years in life expectancy, and with Type II diabetes the reduction is of 3 to 7 years. In addition, patients with Type II diabetes have a two to four times higher tendency of dying from heart disease and are four times more likely to develop peripheral vascular disease and stroke. The number of chronic complications resulting from diabetes is also worth mentioning. These can be microangiopathies (diabetic nephropathy and diabetic retinopathy), macroangiopathies (coronary artery disease, cerebrovascular disease and peripheral vascular disease) and neuropathies. Thus, it is necessary to control this disease and the associated risk factors [21].

One of the limitations of the research was the exclusion of women whose climacteric complaints were absent. However, climacteric symptoms are self-reported complaints; most are subjective in nature and therefore difficult to measure. They can often be overestimated or exacerbated by the participant at the time of collection. The women were also evaluated at a single time point.

\section{Conclusion}

This study not only strengthened the relationship between the presence of risk factors, especially those associated with physical inactivity and overweight, with the prevalence of diabetes and other diseases in the climacteric, but also the importance of the evaluation of sociodemographic factors and their relationship with the increased prevalence of these disorders in the climacteric.

Although there are limitations of this research because it was conducted at a single moment, without intervention, without following the study population, failing to have specific laboratory tests conducted, and self-reporting symptoms, the results raise hypotheses about diabetes that deserve further investigation. Due to the complexity of the issue in question, much remains to be investigated.

\section{References}

1. Silva LMC, Palha PF, Barbosa GR, Protti ST, Ramos AS. Aposentados com diabetes tipo 2 na Saúde da Família em Ribeirão Preto, São Paulo -Brasil. Rev Es Enfer USP [Internet], 2010; 44(2):462-8. DOI: http://dx.doi.org/10.1590/S0080$\underline{62342010000200031}$

2. Franchi KMB, Monteiro LZ, Almeida SB, Pinheiro MHNP, Medeiros AIA, Montenegro RM et al. Capacidade funcional e atividade física de idosos com diabetes tipo 2. Rev Bras Atividade Física \& Saúde [Internet], 2008; 13(3):158-66. Available from: https://www.periodicos.ufpel.edu.br/ojs2/index.php/RBAFS/ article/view/795/804

3. Bosi LP, Carvalho AM, Contrera D, Casale G, Pereira MA, Gronner MF et al. Prevalência de diabetes melito e tolerância à glicose diminuída na população urbana de 30 a 79 anos da cidade de São Carlos, São Paulo. Arq Bras Endocrinol Metab [Internet], São Paulo, 2009; 53(6):726-32. DOI: http://dx.doi. org/10.1590/S0004-27302009000600006

4. Francisco PMSB, Belon AP, Barros MBA, Carandina L, Alves MCGP, Goldbaum M et al. Diabetes auto-referido em idosos: prevalência, fatores associados e práticas de controle. Cad Saúde Pública [Internet], Rio de Janeiro, 2010; 26(1):175-84.

5. Tang M, Chen $Y$, Krewski D. Gender-related differences in the associationbetween socioeconomic status andselfreported diabetes. Int J Epidemiol [Internet], 2003; 32(3):381-5. DOI:10.1093/ije/dyg075

6. Rocha JSB, Freitas RF, Vieira DR, Gomes GV, Costa BL, Reis VMCP. Characterization of perimenopausal women with Diabetes Mellitus Type II about the behavior of self-care. $R$ Bras Qual Vida [Internet], 2013; 5(4):26-35. DOI: 10.3895/S217508582013000400004

7. Lorenzi DRS, Catan LB, Moreira K, Ártico GR. Assistance to the climacteric woman: new paradigms. REBEn [Internet], 2009; 62(2):287-93. DOI: 10.1590/S0034-71672009000200019 
8. Lorenzi DRS, Basso E, Fagundes PO, Saciloto B. Prevalence of overweight and obesity among climacteric women. Rev Bras Ginecol Obstet [Internet], 2005; 27(8):479-84. DOI: 10.1590/ S0100-72032005000800008

9. Hernández BH, Botell ML. Family and work environment, clinical manifestations of chronic diseases present in mean-age women. Rev Cubana Med Gen Integr [Internet], 2009; 25(2):1-13. Available from: http://scielo.sld.cu/pdf/mgi/v25n2/mgi08209.pdf

10. Messier V, Rabasa-Lhoret R, Barbat-Artigas S, Elisha B, Karelis $A D$, Aubertin-Leheudre M. Menopause and sarcopenia: $A$ potential role for sex hormones. Maturitas [Internet], 2011; 68(4):331-6. DOI: 10.1016/j.maturitas.2011.01.014

11. Alberti KG, Zimmet P, Shaw J. Metabolic syndrome-a new worldwide definition. A consensus statement from the International Diabetes Federation. Diabet Med [Internet], 2006; 23(5):46980. DOI: $10.1111 /$ j.1464-5491.2006.01858.x

12. Figueiredo Neto JA, Figueiredo ED, Barbosa JB, Barbosa FF, Costa GRC, Nina VJS et al. Metabolic Syndrome and Menopause: cross-sectional study in gynecology clinic. Arq Bras Cardiol [Internet], 2010; 95(3):339-45. DOI: http://dx.doi.org/10.1590/ $\underline{\mathrm{S} 0066-782 \times 2010005000094}$

13. Alonso ED. Social inequalities and diabetes mellitus. Rev Cubana Endocrinol [Internet], 2013; 24(2):200-13. Available from: http://scielo.sld.cu/pdf/end/v24n2/end09213.pdf

14. Alves ERP, Calazans JCC, Ferreira AYM, Leite GO, Barboza KKS, Dias MD. Associação entre antecedentes ginecológicoobstétricos e sintomas do climatério. REUFSM [Internet]; 2013 Sep; 3(3):490-9. DOI: 10.5902/2179769210567

15. Leite ES, Oliveira FB, Martins IKL, Ramalho KKA, Torquato JA. Perspectives on women climacteric: concepts and impacts on health basic care. Rev Pesqui Cuid Fundam [Internet], 2012 Oct; 4(4):2942-52. Available from: http://www.seer.unirio.br/index. php/cuidadofundamental/article/view/1850/pdf 636

16. Valença CN, Germano RM. Women's conceptions about menopause and climacteric. Rev Rene [Internet], 2010 Jan; 11(1):161-71. Available from: http://www.revistarene.ufc.br/ vol11n1_html_site/a17v11n1.htm

17. Nascimento AB, Chaves EC, Grossi SAA. Depression, urinary cortisol and socialdemographics characteristics in subjectswith type 2 diabetes mellitus. Rev Esc Enferm USP [Internet], 2009 Dec; 43(spe2):1272-6. DOI: 10.1590/S0080-62342009000600022

18. Freitas LRS, Garcia LP. Evolução da prevalência do diabetes e deste associado à hipertensão arterial no Brasil: análise da Pesquisa Nacional por Amostra de Domicílios, 1998, 2003 e 2008. Epidemiol Serv Saúde [Internet], 2012 Mar; 21(1):7-19. DOI: http://dx.doi.org/10.5123/S1679-49742012000100002
19. Pereira JC, Barreto SM, Passos VMA. The profile of cardiovascular health of elderly brazilianpeople needs to improve: a populationbased study. Arq Bras Cardiol [Internet], 2008; 91(1):1-10. DOI: 10.1590/S0066-782X2008001300001

20. Turner RC, Millns H, Neil HA, Stratton IM, Manley SE, Matthews DR et al. Risk factors for coronary artery disease in non-insulin dependent diabetes mellitus: United Kingdom Prospective Diabetes Study (UKPDS: 23). BMJ [Internet], 1998 Mar 14 [cited 2015 Nov 2]; 316(7134):823-8. PMCID: PMC28484

21. Ministério da Saúde (BR). Cadernos de Atenção Básica - n.16 Série A. Normas e Manuais Técnicos. Diabetes Mellitus [Internet]. Brasília: Ministério da Saúde; 2006. Available from: http://bvsms. saude.gov.br/bvs/publicacoes/diabetes mellitus.PDF

\section{Publish in International Archives of Medicine}

International Archives of Medicine is an open access journal publishing articles encompassing all aspects of medical science and clinical practice. IAM is considered a megajournal with independent sections on all areas of medicine. IAM is a really international journal with authors and board members from all around the world. The journal is widely indexed and classified Q1 in category Medicine. 